DOI: $10.1515 /$ pts-2015-0004

\title{
THERMO-INSULATION PROPERTIES OF HEMP-BASED PRODUCTS
}

\author{
V. Lekavicius ${ }^{1}$, P. Shipkovs ${ }^{1}$, S. Ivanovs ${ }^{2}$, A. Rucins ${ }^{2}$ \\ ${ }^{1}$ Institute of Physical Energetics, \\ 21 Aizkraukles Str., Riga, LV-1006, LATVIA \\ ${ }^{2}$ Agency of Latvia University of Agriculture Research \\ Institute of Agricultural Machinery, \\ 1 Instituta Str., Ulbroka, Stopinu nov., LV-2130, LATVIA
}

\begin{abstract}
As known, many multi-purpose plants can be used in different industries. This research is focused on the possibilities to utilize hemp as feedstock for thermal insulation products. The most advantageous features of hemp insulation are associated with health and environmental safety. The thermal conductivity of commercially available hemp insulation products is comparable with that of other fibrous insulation materials; however, it is possible to develop new products that could be more efficient in terms of cost and due to other important features.
\end{abstract}

Keywords: hemp thermal insulation, thermal conductivity, thermal insulation materials.

\section{INTRODUCTION}

Rapid changes in the energy prices and incessant debates on climate change impose increasing requirements on the energy efficiency. The power consumption for heating and cooling of buildings makes up a considerable share of the total energy consumption in Europe. Therefore, requirements for insulation of buildings, and, consequently, demand for insulation materials are growing. Particularly strong trend exists towards natural and environment-friendly insulation materials. One of the natural local resources for production of insulation materials is hemp (Cannabis sativa L.). The purpose of this research is to analyze the context and specific features of hemp-based thermal insulation products.

Currently, insulation materials produced from hemp make up only a small share in the European market for thermal insulation products. According to the IAL Consultants data, the total market for thermal insulation products in Europe reached approximately 193 million $\mathrm{m}^{3}$ in 2012 , whereas the value of this market was estimated at 9.6 billion euro [1]. The share of hemp insulation materials in this market can be considered as very small in terms of physical volume and value (both much less than $1 \%$ of the total market size). However, hemp insulation materials are of considerable promise for the future if we take into account increasing environmental awareness of people. 


\section{HEMP IN EUROPE: GROWING AND UTILIZATION}

Although the climatic conditions are suitable for hemp fibre growing almost in the whole Europe, considerable amounts of hemp are traditionally grown only in several countries. This is also connected with legal issues: in some countries growing hemps of definite type is forbidden due to possible use as a drug substance.

The top producers of hemp straw in Europe are France (42.7 thousand tons in 2011), Germany, United Kingdom, and the Netherlands. The actual numbers are varying considerably from year to year, depending on the realization opportunities and other factors. Even in France, the land area used for hemp was only 5400 ha in 2011, while in 2009 this area was 11300 ha [2]. Such a lack of steady trend gives a ground for arguing that hemp is a niche product that is highly dependent on the market conjuncture and other external factors. Furthermore, the changes in hemp cultivation area show that in European countries there are no strict constraints on the area for hemp production. The flows of hemp straw are depicted in Fig. 1.

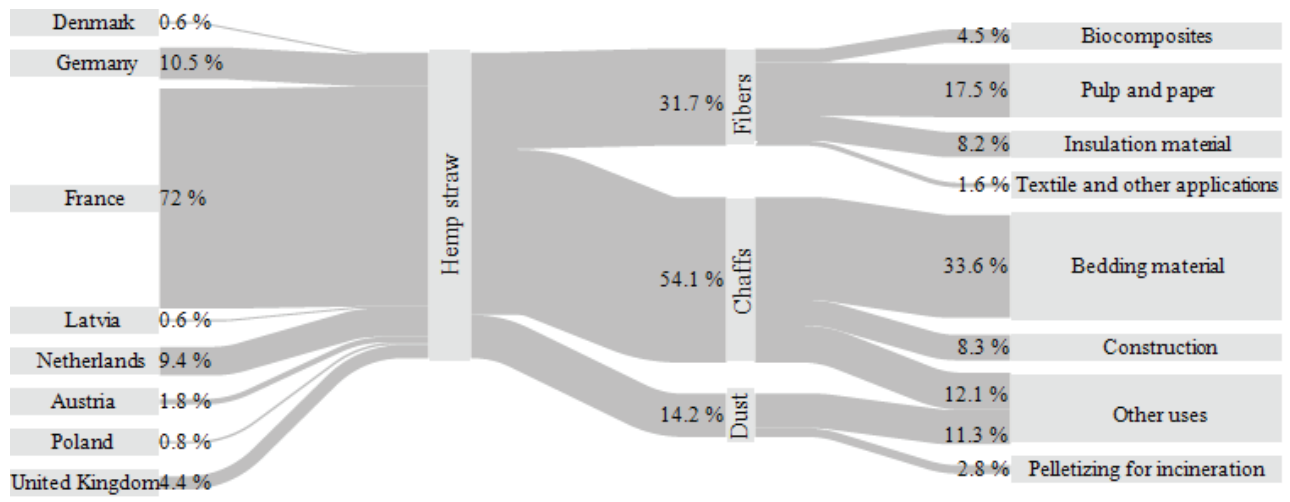

Fig. 1. Production and utilization of hemp straw in the European Union [2], [3].

Particular parts of hemp straw can be utilized in various ways. Although the proportions in Fig. 1 are not fixed on this aspect, this picture illustrates a usual practice in 2010 and shows the potential for different hemp straw utilization.

According to the data from the European Industrial Hemp Association, insulation materials occupy one of the most important utilization areas of hemp fibres: in $2010,25.9 \%$ hemp fibres were used in production of insulation materials. Moreover, $15 \%$ hemp chaffs were utilized in the construction industry, mainly for production of the so-called hempcrete [3]. This substance can be defined as a lightweight insulating and breathable material produced by mixing hemp chaffs with a lime base binder and water. As compared with conventional concrete, such a mixture has different mechanical and acoustic properties [4]. The empirical tests show that the addition of some amount of hemp to a mortar improves the thermal performance of the material and makes it lighter [5]. Hempcrete can be used for insulation quilts, floors, roofs, screeds, mortars or insulation plasters which can be either cast or sprayed. Hemp chaffs can also be used for producing hemp bricks based on the principle similar to 
that for hempcrete production [4]. Hemp chaffs may be utilized in biodegradable boards for different lightweight constructions, such as mobile homes, packing material, etc. [6]. It should be noted that the quantitative relationship between fibres and chaffs is here more or less stable. Therefore, if the market for one of these materials (e.g. fibres) is expanding, the supply of the other one is also increasing. Thus, it is expected that hemp chaffs have a big potential for improving the construction business in terms of sustainability [7].

Another potential hemp utilization area is fuel for direct burning or feedstock for pellet production. The most important properties of some biomass fuels are compared in Table 1.

Table 1

Calorific Values of Biomass Fuels [8]

\begin{tabular}{|l|c|c|c|}
\hline \multirow{2}{*}{ Material } & \multicolumn{2}{|c|}{ Calorific value (MJ/kg) } & \multirow{2}{*}{$\begin{array}{l}\text { Assumed } \\
\text { Moisture content (\%) }\end{array}$} \\
\cline { 2 - 4 } & Gross & Net & 20 \\
\hline Hemp & 18.5 & 13.4 & 40 \\
\hline Wood residues & 19.7 & 10 & 20 \\
\hline Straw & 18 & 13 & 50 \\
\hline Peat & 21.5 & 8.9 & \\
\hline
\end{tabular}

Although the hemp pellet production for domestic use can be limited, big boilers for industrial heating or power generation are seen as a promising option of hemp utilization. One of the most attractive advantages of hemp is that it can be field-dried to $20 \%$ moisture. In this case, its net calorific value (the heat available with no further drying and no recovery of latent heat) is higher than that of many other forms of biomass and much higher than that of peat [8].

To sum up, approximately $16.5 \%$ of hemp straw is currently used in the construction sector as insulation or building material. As to the potential applications, it might be good if the part of hemp chaffs currently used as bedding material could be utilized in construction or consumed as fuel. This makes hemp a true energy plant, with the potential of being both energy conservation material and energy resource. Moreover, in both the usage directions, hemp has a true potential for reducing greenhouse gas emissions.

\section{THE FEATURES OF HEMP INSULATING MATERIALS}

The features of insulating materials are traditionally classified into three main groups: physical, environmental and health-related [9].

The first group of features deals with the traditional physical parameters - i.e. density, thermal conductivity, sound absorption - that can be measured using standard procedures.

The measurement of parameters belonging to the second group is much more 
complicated, since the evaluation of life-cycle environmental impacts depends on many assumption-based factors, and sometimes might be subjective. Possible impact on the climate change is also accounted for among environmental features, a good case in this important point being the ozone depletion potential of chemical materials, such as chlorofluorocarbons and hydrochlorofluorocarbons that are emitted during the life cycle of some foam-type insulation materials (e.g., extruded polystyrene, polyisocyanurate) [10]. A more comprehensive approach to the environmental issues also includes the use of primary energy in the process of insulating material production as was the case in the model integrated of life-cycle costing and dynamic thermal simulation (MILD). The application of this model for a sheep farm in the Italian Apennines has shown that the best performances are obtained for glass wool, sheep wool and hemp fibre. If the criterion of primary energy input cost is eliminated, the polyurethane passes from the least to the most preferable material [11]. Thus, inclusion of environmental criteria highlights the advantages of hemp and other natural insulation materials over synthetic ones.

Similarly to the second group, the third one deals with the issues that might appear at any stage of the life cycle of a material, but in practice the main attention is paid to the dust emissions and toxicity during the installation and use of material, a good illustration being glass wool that might cause health-related problems such as respiratory diseases to the personnel involved in the installation works. Health-related features can depend not directly on the insulation material itself, but also on the suitable conditions for the usage of a particular insulation material. Sometimes there is a need to perform careful calculations in order to ensure good microclimate in the building and avoid mould that might be a cause of many medical disorders.

In addition to these groups of features, economic characteristics, such as the price of insulating material itself or the cost of installation, must also be mentioned as important for insulating materials.

The above-mentioned groups are usually closely interrelated: poor hygric properties may result in deterioration of thermal insulation ability and mould proliferation; the use of toxic materials in the production process causes both environmental and health problems, etc.

In practice, the actual choice of insulating material for a building depends also on other objective and subjective factors related to its peculiarities, the existing (or foreseen) heating (cooling) system, and the consumer's preferences considering the importance of each element in above mentioned groups of features. The decision made is usually a result of considerations that are based on many factors associated with specific weights that express the importance of each factor. In some cases, highly-skilled experts and quite complex multiple-criterial decision making methods are employed in order to choose the most suitable material [12].

The characteristics of a particular thermal insulation product may depend on many factors, including its composition, quality of feedstock, technology that is used for its production, etc. A brief description of some hemp insulation materials that are currently available in the market is provided in Table 2. 
Properties of Hemp Thermal Insulation Products Available in the Market

\begin{tabular}{|c|c|c|c|c|c|}
\hline $\begin{array}{l}\text { Thermo-Insu- } \\
\text { lation product }\end{array}$ & Composition & $\begin{array}{l}\text { Thermal } \\
\text { Conduc- } \\
\text { tivity, } \\
\mathrm{W} /(\mathrm{m} \cdot \mathrm{K})\end{array}$ & $\begin{array}{l}\text { Specific } \\
\text { Thermal } \\
\text { Capacity } \\
\mathrm{J} /(\mathrm{kg} \cdot \mathrm{K})\end{array}$ & $\begin{array}{l}\text { Den- } \\
\text { sity, } \\
\mathrm{kg} / \mathrm{m}^{3}\end{array}$ & $\begin{array}{l}\text { Infor- } \\
\text { mation } \\
\text { Source }\end{array}$ \\
\hline 1. & 2. & 3. & 4. & 5. & 6. \\
\hline NatuHemp & $\begin{array}{l}95 \% \text { natural hemp fibres, } 5 \% \\
\text { recycled adhesive binder }\end{array}$ & 0.039 & 1700 & 30 & [13] \\
\hline $\begin{array}{l}\text { HempFlax } \\
\text { Nature } \\
\text { Insulation }\end{array}$ & $\begin{array}{l}90 \% \text { hemp fibres reinforced } \\
\text { with } 10 \% \text { Bico or PLA (corn } \\
\text { starch) fibre. Soda has been } \\
\text { added as a fire deterrent. }\end{array}$ & 0.04 & 1800 & 35 & [14] \\
\hline Nature PRO & Hemp fibres & 0.04 & n. a. & 28 & {$[15]$} \\
\hline Thermo-Hemp & $\begin{array}{l}82-85 \% \text { hemp fibres, } \\
10-15 \% \text { bi-component fibres, } \\
3-5 \% \text { sodium bicarbonate }\end{array}$ & 0.038 & $\begin{array}{l}1600- \\
2300\end{array}$ & $30-42$ & {$[16,17]$} \\
\hline $\begin{array}{l}\text { Thermafleece } \\
\text { Natra Hemp }\end{array}$ & $\begin{array}{l}60 \% \text { UK grown hemp, } 30 \% \\
\text { recycled polyester and } 10 \% \\
\text { polyester binder with a high } \\
\text { recycled content. }\end{array}$ & 0.04 & 1800 & 25 & [18] \\
\hline $\begin{array}{l}\text { Hemptechnol- } \\
\text { ogy Breathe }\end{array}$ & $\begin{array}{l}\text { Hemp } 47.5 \% \text {, flax } 47.5 \% \text {, } \\
\text { polyester } 5 \%\end{array}$ & 0.039 & n. a. & 30 & [19] \\
\hline $\begin{array}{l}\text { Saint-Gobain } \\
\text { Isover Vegetal } \\
\text { insulation }\end{array}$ & $\begin{array}{l}\text { Hemp and recycled cot- } \\
\text { ton (up to } 40 \% \text { ), polyester } \\
\text { binder, phosphate- based fire } \\
\text { retardant, treatment to avoid } \\
\text { mould proliferation. }\end{array}$ & $\begin{array}{c}0.039- \\
0.041\end{array}$ & n. a. & 35 & {$[20]$} \\
\hline Isonat végétal & $\begin{array}{l}\text { Hemp fibres } 42.5 \% \text {, recycled } \\
\text { cotton } 42.5 \% \text {, textile fibres } \\
\text { (recycled polyester) } 15 \%\end{array}$ & 0.041 & n. a. & 35 & {$[21]$} \\
\hline $\begin{array}{l}\text { Fibranatur } \\
\text { Isolant Ouate de } \\
\text { chanvre }\end{array}$ & $\begin{array}{l}90 \% \text { hemp fibres, polyester } \\
\text { binder }\end{array}$ & 0.04 & 1800 & 40 & {$[22]$} \\
\hline Biofib'hemp & $\begin{array}{l}90 \% \text { hemp fibres, polyester } \\
\text { binder - natural binder (op- } \\
\text { tional) }\end{array}$ & 0.04 & 1800 & 40 & [23] \\
\hline $\begin{array}{l}\text { Lenofon Com- } \\
\text { ponents Hemp } \\
\text { Fibre Panel }\end{array}$ & $\begin{array}{l}\text { Mainly hemp fibres, a small } \\
\text { proportion of bi-component } \\
\text { fibres, and soda for fire pro- } \\
\text { tection }\end{array}$ & 0.041 & 1600 & 38 & {$[24]$} \\
\hline
\end{tabular}


Table 2 continuation

\begin{tabular}{|l|l|c|c|c|c|}
\hline \multicolumn{1}{|c|}{1.} & \multicolumn{1}{|c|}{2.} & 3. & 4. & 5. & 6. \\
\hline $\begin{array}{l}\text { Technichanvre } \\
\text { hemp wool } \\
\text { TECHNILAINE }\end{array}$ & $\begin{array}{l}\text { 85\% of hemp fibres, 15\% of } \\
\text { stable synthetic binder, non- } \\
\text { emissive }\end{array}$ & $\begin{array}{c}0.04 \\
(0.048 \\
\text { when } \\
\text { wet })\end{array}$ & 1370 & $25-30$ & {$[25]$} \\
\hline $\begin{array}{l}\text { STEICO canaf- } \\
\text { lex }\end{array}$ & $\begin{array}{l}\text { Hemp fibres, ammonium } \\
\text { phosphate, polyolefin fibres }\end{array}$ & 0.043 & 1700 & 40 & {$[26]$} \\
\hline
\end{tabular}

Most of the hemp insulating products reviewed are produced from hemp fibres by adding synthetic or natural binder and additional materials that are needed to increase the fire resistance and, sometimes, mould proliferation. The composition of hemp insulating materials as well as the whole hemp insulation producers' marketing strategy shows a clear orientation towards environmentally concerned consumers: some producers provide the opportunity of choosing between polyester and natural binders, while others stress the fact that recycled materials are used in the production process.

There are also other properties that are usually mentioned among advantages of hemp insulation: high acoustic performance; possibility to reuse; low level of toxins; convenient installation (there are no irritating fibres; they are easy to cut); robustness in handling, transportation, and onsite construction; vapour permeability. However, there are also some limitations: relatively (in comparison with non-natural competitors) high price; requirement for thicker walls due to lower thermal conductivity (in comparison with polystyrene, etc.); application limits due to finishing; natural insulation is not always produced locally [27]. The last point of limitations is especially important when environmental impact of an insulating material is assessed. However, looking to the positive side of this issue, it is possible to argue that wide spread of local resources as well as positive social impact on the local communities might be among other advantages of hemp-based insulation.

Coming back to the above mentioned groups of features, it might be concluded that the strongest sides of hemp insulation are related to the environmental and health-related issues, while physical and economic properties require deeper analysis in each particular case, when the decision regarding the use of insulation material is going to be taken.

\section{THERMAL CONDUCTIVITY OF HEMP INSULATION PRODUCTS}

Among other factors, thermal conductivity plays the central role in the performance evaluation of an insulating material. The lower thermal conductivity of the insulating material, the greater its ability to resist heat transfer and, hence, the greater is the effectiveness of the insulation. Thermal conductivity is used for calculation of other common measurements: thermal resistance (R-value) and thermal transmittance ( $U$-value) [28].

The $R$-value is calculated by the following equation:

$$
R=\frac{l}{\lambda},
$$


where $\lambda$ is the thermal conductivity, and $l-$ the thickness of the material. The $U$ value is described as inverse of $R$-value, thus for monolithic surfaces the former can be calculated as

$$
U=\frac{\lambda}{l} .
$$

For multi-layer surfaces, the thermal resistance and the thermal conductivity of each layer have to be taken into account.

\section{A. The importance of thermal conductivity for economic attractiveness of insulating material}

Despite the fact that external insulation allows full use of the thermal mass and is the best insulation option [29], there are many cases when exterior insulation is not feasible. Strict regulations for preservation of the façade of an historic building or difficulties in decision-making regarding renovation of a multifamily house are among good cases in this regard. In such circumstances the insulating materials are used for insulation of the inner surface of walls. Taking into account that the inner insulation is sometimes the only option for insulating historic and heritage buildings in old-towns and other most expensive areas of cities, the worth of area loss can be greater than the cost of insulation material itself. Thus, thermal conductivity and, respectively, insulation thickness, has a distinctive economic meaning, which might be a serious argument influencing the choice of a particular insulation material. This can be illustrated by the results of hypothetical insulation cost calculations given in Table 3 .

In the mentioned table, two cases of insulation are considered, each of them intentionally not associated with a particular insulation material. The insulation in the first case is twice as expensive as that in the second case if only prices per cubic metre of insulation material are compared. Nevertheless, the thermal conductivity of insulation used in Case 2 is inferior. The calculations revealed that for the same $U$-value of 0.2 it is necessary to use $11.9 \mathrm{~cm}$ thick insulation in Case 1 and $15.8 \mathrm{~cm}$ - in Case 2. This increases the relative price of insulation in Case 2, but still remains lower than that in Case 1. Assuming the real estate price to be $2000 \mathrm{EUR} / \mathrm{m}^{2}$, it can be found that the cost of space lost in Case 2 compared with Case 1 is worth of $(15.8-11.9) / 100 \cdot 2000=78$ euro per length metre of insulation. Dividing this number by the ceiling height, we obtain the cost difference of 28.89 euro per square metre of insulation.

Table 3

Simplified Insulation Cost Calculations*

\begin{tabular}{|l|c|c|}
\hline & Case 1 & Case 2 \\
\hline & 1. & 2. \\
\hline Ceiling height $(m)$ & \multicolumn{2}{|c|}{2.7} \\
\hline U-value before insulation $\left(\mathrm{m}^{2} \cdot \mathrm{K} / \mathrm{W}\right)$ & \multicolumn{2}{|c|}{0.96} \\
\hline Real estate price $\left(E U R / \mathrm{m}^{2}\right)$ & \multicolumn{2}{|c|}{2000} \\
\hline $\begin{array}{l}\text { Thermal conductivity of insulating material } \\
(\boldsymbol{W} /(\boldsymbol{m} \cdot \mathbf{K}))\end{array}$ & $\mathbf{0 . 0 3}$ & $\mathbf{0 . 0 4}$ \\
\hline
\end{tabular}


Table 3 continuation

\begin{tabular}{|c|c|c|}
\hline & 1. & 2. \\
\hline Price of insulating material $\left(E U R / m^{3}\right)$ & 100 & 50 \\
\hline $\begin{array}{l}\text { Insulation thickness required to reach } U \text {-value of } 0.2 \\
\left(\mathrm{~m}^{2} \cdot \mathrm{K} / \mathrm{W}\right), \mathrm{cm}\end{array}$ & 11.9 & 15.8 \\
\hline Thickness of the finishing $(\mathrm{cm})^{* *}$ & 1.5 & 1.5 \\
\hline Total additional thickness $(\mathrm{cm})$ & 13.4 & 17.3 \\
\hline Loss of floor space $\left(\mathrm{m}^{2}\right.$ per $\mathrm{m}^{2}$ of insulated wall surface) & 0.050 & 0.064 \\
\hline $\begin{array}{l}\text { Cost of insulating material }\left(\mathrm{EUR} / \mathrm{m}^{2} \text { of insulated wall }\right. \\
\text { surface) }\end{array}$ & 11.88 & 7.92 \\
\hline $\begin{array}{l}\text { Cost of installation and finishing (EUR } / m^{2} \text { of insulated } \\
\text { wall surface) }\end{array}$ & 30.00 & 30.00 \\
\hline Cost of space lost (EUR/m² of insulated wall surface) & 99.07 & 128.40 \\
\hline $\begin{array}{l}\text { Total cost of insulation (EUR/m } \mathrm{m}^{2} \text { of insulated wall } \\
\text { surface) }\end{array}$ & 140.95 & 166.31 \\
\hline
\end{tabular}

* Assumptions are provided in italics.

** It is assumed that finishing has no impact on $U$-value calculated.

In the example provided in Table 3, the differences in the value of space lost are the main factor that determines the total cost of insulation, as it accounts for more than $70 \%$ of the total insulation cost in both cases, while the cost of insulating material makes only $8.4 \%$ in Case 1 and $4.8 \%$ in Case 2 . Thus, even if only economic criteria are considered, the price of the insulating material is not necessarily the most important cost component, and other indirect conductivity-related factors can play the dominant role.

\section{B. Thermal conductivity of hemp insulation in the context of other insu- lating materials}

The thermal conductivity of commercially available hemp insulation products under consideration is in the range of $0.038-0.043 \mathrm{~W} /(\mathrm{m} \cdot \mathrm{K}$ ) (see Table 2). This range is much tighter than can be found in scientific literature, where thermal conductivity of hemp insulation is reported to be up to $0.094 \mathrm{~W} /(\mathrm{m} \cdot \mathrm{K})$ [30]. Comparison of the thermal conductivity of hemp insulation with that of other insulating materials is provided in Fig. 2. In this figure, the data about all insulation material types, except hemp insulation, are based on wide research which covers around eight thousand thermal conductivity measurements of insulating materials [31]. 


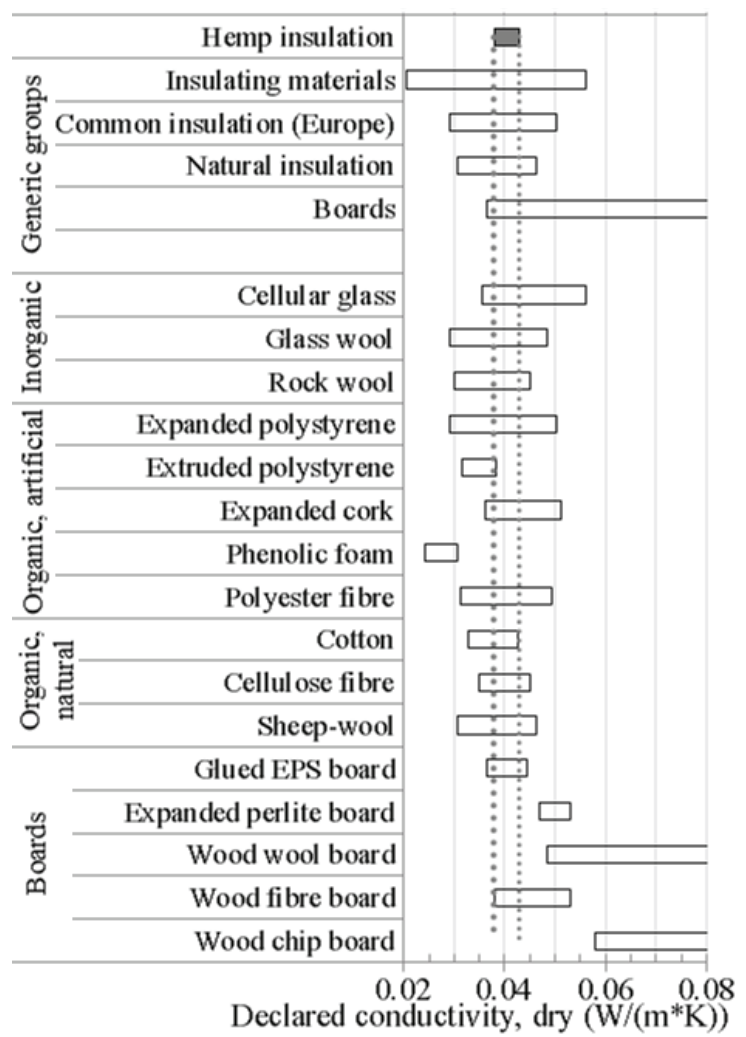

Fig. 2. Thermal conductivity of hemp insulation as compared with other insulating materials (information source for other materials: [31]).

The thermal conductivity of hemp insulation falls within the ranges of all generic groups of the insulation and is comparable with those of other fibrous insulation materials. This is also valid for natural organic insulation, as average thermal conductivities of cotton, cellulose fibres, and sheep-wool insulation are comparable with the declared values of thermal conductivity of hemp insulation.

\section{The thermal conductivity determinants of hemp insulation}

The heat can be transferred through an insulation material by combined heat transfer modes: solid conduction through the solid matrix; natural convection and gas conduction in the space between fibres, and radiation interchanging in participating media. However, under normal operating conditions, the contribution of natural convection is negligible $[31,32]$.

Generally, a relationship exists between the conductivity of an insulating material and its density. When the density is low, the conductivity increases with density decreasing due to high air permeability. Also, a loose structure of fibres allows for heat propagation in the field of infrared. Thermal conductivity decreases due to increasing density because of weaker radiation and streaming. However, at high densities the conductivity increases with density due to increasing transmission of heat in the solid phase by conduction [33]. To put it simpler, in this case the increase in conductivity is determined by the decrease in the porosity of the insulating material. 
This can be expressed by a polynomial function which consists of the conductive and radiative members. The conductive member is expressed with the following equation:

$$
\lambda_{\text {cond }}=a+b \rho,
$$

where $\rho$ is the density of insulating material.

In turn, the radiative member is expressed as

$$
\lambda_{\text {rad }}=\frac{\mathrm{c}}{\rho} \text {. }
$$

This equation depicts the principle that with the density increasing the more solid shields that block radiant exchange are found in the structure of insulating material [31].

The total conductivity is expressed as the sum of (1) and (2):

$$
\lambda=a+b \rho+\frac{c}{\rho} .
$$

\section{RESULTS AND DISCUSSION}

The estimation of coefficients for Eq.(5) and for simple linear relationship (3) was based on the data about commercially available hemp insulation materials presented in Table 2. However, cases with the density or conductivity ranges only were excluded in order to avoid sensitivity of the results to subjective choice of a particular value within the range provided. Thus, the estimation was performed using 10 observations. The results of estimation are shown in Fig. 3.

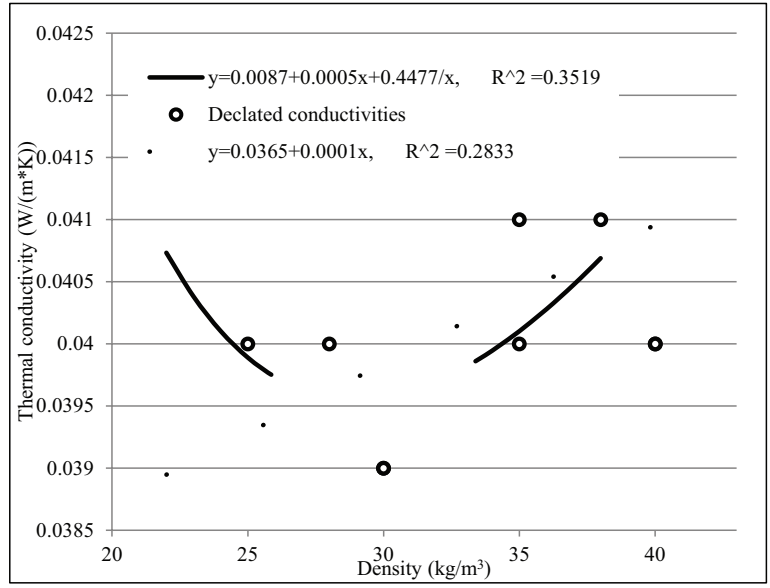

Fig. 3. The relationship between the thermal conductivity and the density of hemp insulation products.

Curves of Fig. 3 generated by Eqs (3) and (5) have relatively low proportions of variance. Moreover, following the interpretation provided by DomínguezMuñoz et al. [31], the first member of Eq.(3) should be the constant conductivity of air $(\sim 0.024 \mathrm{~W} /(\mathrm{m} \cdot \mathrm{K}))$. Using the data of commercially available hemp insulation products, this part of equation could be estimated at the level of $0.0087 \mathrm{~W} /(\mathrm{m} \cdot \mathrm{K})$, which is lower than any corresponding coefficient in [31], i.e. in the range of 0.0146 - 
$0.0356 \mathrm{~W} /(\mathrm{m} \cdot \mathrm{K})$. For this, there might be several explanations. First, commercial hemp insulation products have different compositions. Addition of some materials in order to reduce the fire resistance, the choice of binder, and mixing hemp fibres with other insulating materials might have different impacts on the density and thermal conductivity, which will consequently result in a limited fit to the equation. Second, for the analysis the officially declared values were used. However, only few producers provided official certificates. It is possible that some producers measure only the density (as this requires relatively straightforward procedures), while the conductivity is based on theoretical assumptions instead of experimental data. Third, even the density in some cases is provided with quite a wide range and can be not exact enough: as a natural product, hemp insulation experiences some limitations in ensuring fixed properties. This can be illustrated by the fact that the average declared density of the hemp insulation material sample analyzed in this research is $34 \mathrm{~kg} / \mathrm{m}^{3}$, while the measured mean density of another sample of five fibrous hemp insulation materials commercially available in the United Kingdom is $50 \mathrm{~kg} / \mathrm{m}^{3}$ [34]. Finally, the experimental investigations sometimes also involve certain methodological aspects that limit their comparability with industrial products [35].

The estimation of Eq. (5) shows that the minimum thermal conductivity is obtained at the hemp insulation density of $29 \mathrm{~kg} / \mathrm{m}^{3}$. In principle, this is in line with the general observation that the lowest conductivities for the majority of insulating materials are found in the density range of $30-60 \mathrm{~kg} / \mathrm{m}^{3}[31]$ as well as with a similar result $\left(32 \mathrm{~kg} / \mathrm{m}^{3}\right)$ obtained for the Purini hemp variety [36].

This result, however, contradicts the data of experimental research [33] that shows the minimum conductivity being at the density of approx. $77 \mathrm{~kg} / \mathrm{m}^{3}$. It might be good that this difference is caused by fundamentally different compositions of hemp-based insulation products: the set of commercially available materials of the type analyzed in this research consist mainly of hemp fibres. On the contrary, in [33] the mixtures including 16-41\% hemp chaffs were analyzed. The analysis of experimental data provided in [33] shows a correlation of 0.49 between the chaff share and the density, while the correlation between the chaff share and the thermal conductivity is 0.26 .

Another research dealing with similar matter shows that the thermal insulation material where the hemp chaff dominates has a higher thermal conductivity than hemp fibre material. Moreover, densities of materials with considerable share of hemp chaff are also higher (the density of hemp fibre material is reported to be $26 \mathrm{~kg} / \mathrm{m}^{3}$, while the densities of the samples where the hemp chaff dominates are in the range of 132-141 kg/m $\mathrm{m}^{3}$ [35]. These trends are also supported by the research where correlation between thermal conductivity and density of pure hemp chaffs was analyzed [35]. The experiments were performed in the density range of 92$108 \mathrm{~kg} / \mathrm{m}^{3}$, and it was shown that due to density increase the thermal conductivity decreases linearly from $0.055 \mathrm{~W} /(\mathrm{m} \cdot \mathrm{K})$ to $0.051 \mathrm{~W} /(\mathrm{m} \cdot \mathrm{K})$ [37]. Therefore, the use of hemp chaffs for thermal insulation might be efficient, considering the ratio between the cost and the thermal properties.

On balance, the results of experimental research works are highly dependent on the methodology of each experiment; however, the overview of relevant information gives some grounds for supposing that inclusion of hemp chaffs into the 
insulation material would: a) increase the density of the material; b) increase the thermal conductivity; c) shift the "optimal density" (i.e. providing the lowest thermal conductivity) to the zone of higher densities.

\section{CONCLUSIONS}

The conclusions based on the results of work are as follows.

Hemp is a multi-purpose plant which can be utilized in different industries. Possibility to use hemp both for fuel and as feedstock for thermal insulation makes it a true energy plant. In such usage directions as green energy production and increasing the energy efficiency, hemp has a true potential to reduce greenhouse gases emissions

Currently, considerable proportion of hemp fibres is used for production of insulating materials; however, it is feasible to extend this market not only by increasing the hemp growing and insulation production volumes, but also by developing new hemp-based insulation products.

The most advantageous features of hemp insulation are related to health and environmental benefits. The orientation towards environmentally cautious consumers is also reflected in the marketing strategies of enterprises that produce and sell hemp-based insulation materials.

Thermal conductivity is one of the most important parameters of any insulating material. However, its economic interpretation depends on the way the material is made and on other features, e.g. the price of real estate in the case of inner insulation. The thermal conductivity of commercially available hemp insulation products is in the range of $0.038-0.043 \mathrm{~W} /(\mathrm{m} \cdot \mathrm{K})$ - i.e. falls within the thermal conductivity ranges of all generic groups of the insulation and is comparable with that of other fibrous insulation materials.

Analysis of the thermal conductivity/density ratios has revealed that the minimum declared thermal conductivity is obtained at the declared hemp fibres insulation density of $29 \mathrm{~kg} / \mathrm{m}^{3}$. Hemp chaffs also have a potential for use as an efficient thermal insulation, at least considering the relationship between the cost and the thermal properties.

\section{ACKNOWLEDGEMENT}

This work is supported by the ESF "Attraction of Human Resources to Science ( $2^{\text {nd }}$ round)" project "Development of the innovative technologies for the accumulation and production of heating and cooling" No 2013/0064/1DP/1.1.1.2.0/13/APIA/ VIAA/050.

\section{REFERENCES}

1. IAL Consultants. The European Market for Thermal Insulation Products 2013; http:// www.ialconsultants.com/uploads/CUBE_press_release/2013-03 14/EUThermal\%20Inspressrelease2013.pdf.

2. Directorate General for Agriculture and Rural Development of the European Commission, Agriculture in the European Union - statistical and economic information. Report 2013. 
3. Carus, M. (2013) Market Data on Industrial Hemp - Fibres, Shivs and Seeds.; Available from: http://www.fibrafp7.net/Portals/0/Michael_Carus_Day_1.pdf.

4. Matshwi, T. and K. Kajimo-Shakantu. (2014) Potential of Hemp as an alternative sustainable component in building materials in World Sustainable Building 2014. Barcelona.

5. Benfratello, S., et al., (2013) Thermal and structural properties of a hemp-lime biocomposite. Construction and Building Materials, 48: p. 745-754.

6. Theis, M. and B. Grohe, (2002) Biodegradable lightweight construction boards based on tannin/hexamine bonded hemp shaves. Holz als Roh- und Werkstoff, 60(4): p. 291-296.

7. Heller, K., et al., (2014) Fibres that can be produced in EU27.

8. Rice, B., (2008) Hemp as a Feedstock for Biomass-to-Energy Conversion. Journal of Industrial Hemp, 13(2): p. 145-156.

9. Papadopoulos, A.M., (2005) State of the art in thermal insulation materials and aims for future developments. Energy and Buildings, 37(1): p. 77-86.

10. Sadineni, S.B., S. Madala, and R.F. Boehm, (2011) Passive building energy savings: A review of building envelope components. Renewable and Sustainable Energy Reviews, 15(8): p. 3617-3631.

11. Menconi, M.E. and D. Grohmann, (2014) Model integrated of life-cycle costing and dynamic thermal simulation (MILD) to evaluate roof insulation materials for existing livestock buildings. Energy and Buildings, 81: p. 48-58.

12. Zagorskas, J., et al., (2014) Thermal insulation alternatives of historic brick buildings in Baltic Sea Region. Energy and Buildings, 78: p. 35-42.

13. NatuHemp Technical sheet. Nov. 1, 2014; http://www.blackmountaininsulation.com/ NatuHemp_Technical_Sheet.pdf.

14. HempFlax Nature Insulation. Nov. 3, 2014; http://hempflax.com/en/products/hempflaxproducts-for-construction/hempflax-nature-insulation.

15. naturePRO, H.p.i. Nov. 3, 2014. http://www.natureproinsulation.co.uk/pdf/Hemp-Leaflet-High-Res.pdf.

16. Ecological Building Systems. Thermo-Hemp. Nov. 3, 2014; http://www.ecologicalbuildingsystems.com/products/insulation/thermo-hemp/.

17. Thermo-Hemp. Thermo-Hemp natural Insulation. Nov. 3, 2014; http://www.ecologicalbuildingsystems.com/workspace/downloads/Thermo-Hemp.pdf.

18. Thermafleece. Thermafleece NatraHemp natural insulation. Nov. 3, 2014; http://www. thermafleece.com/product/thermafleece-natrahemp.

19. hemptechnology. Breathe Natural Fibre Insulation. Nov. 3, 2014; http://americanlimetechnology.com/wp-content/uploads/2011/11/Breathe-Datasheet.pdf.

20. Saint-Gobain Isover. Vegetal insulation. Nov. 3, 2014; http://www.isover.com/Our-solutions/Insulation-materials/Vegetal-insulation.

21. Isonat Végétal. Une isolation thermique et acoustique performante et une grande souplesse de mise en couvre! Nov. 3, 2014; http://www.isonat.com/uploads/files/ produits/IsonatVegetal/Fiche_Vegetal_1113_BDEF.pdf.

22. Fibranatur. Isolant chanvre. Nov. 3, 2014; http://www.fibranatur.com/isolant-naturelchanvre-fibranatur-p2.php.

23. Biofib. Biofib'Hemp: 100\% hemp natural insulation. Nov. 3, 2014; http://www.biofibisolation.com/biofib-chanvre.php? $\mathrm{L}=\mathrm{EN}$.

24. lenofon. lenofon Components. Nov. 3, 2014; http://www.lenofon.com/en/komponentenhanfplatte.htm. 
25. Technichanvre. Hemp insulation: rolls and panels. Nov. 3, 2014; http://www.technichanvre.com/1411-2/1499-2/hemp-insulationrolls-and panels/?lang=en\#dws_first_tab33.

26. Steico canaflex: flexible thermal insulation from hemp. Nov. 3, 2014; http://merodax. com/images/dokumentai/steico_canaflex_merodax_en.pdf.

27. Sutton, A., D. Black, and P. Walker, (2011) Natural Fibre Insulation: An introduction to low-impact building materials.

28. AEA, Green Public Procurement Thermal Insulation. Technical Background Report. 2010.

29. Curtis, R., (2010) Climate Change and Traditional Buildings: The Approach Taken by Historic Scotland. Journal of Architectural Conservation, 16(3): p. 7-27.

30. Kymäläinen, H.-R. and A.-M. Sjöberg, (2008) Flax and hemp fibres as raw materials for thermal insulations. Building and Environment, 43(7): p. 1261-1269.

31. Domínguez-Muñoz, F., et al., (2010) Uncertainty in the thermal conductivity of insulation materials. Energy and Buildings, 42(11): p. 2159-2168.

32. Zhao, S.-y., B.-m. Zhang, and X.-d. He, (2009)Temperature and pressure dependent effective thermal conductivity of fibrous insulation. International Journal of Thermal Sciences, 48(2): p. 440-448.

33. Zach, J. and J. Hroudova. (2010) Utilization of Technical Hemp for Thermal Insulating Materials Production. in Second International Conference on Sustainable Construction Materials and Technologies. Ancona.

34. Latif, E., et al., (2014) Hygric properties of hemp bio-insulations with differing compositions. Construction and Building Materials, 66: p. 702-711.

35. Andzs, M. and V. Skrupskis, (2011) Possible Use of Hemp and Wood in Production of the Heat Insulation Materials, in 8th International Scientific and Practical Conference "Environment. Technology. Resources". Rēzekne.

36. Freivalde, L., (2014) Tehnologiju ietekme uz kaņepju šķiedru siltumizolācijas materiālu ìpašībām, Rīga: RTU.

37. Balčiūnas, G. and S. Vejelis. (2012.) Kanapiu spaliu fizikiniu savybiu tyrimai. in 15th Conference for Junior Researchers „, Science - Future of Lithuania “.

\title{
KAN̦EPJU SILTUMIZOLĀCIJAS MATERIĀLU İPAŠĪBAS
}

\author{
V. Lekavičius ${ }^{1}$, P. Šipkovs ${ }^{1}$, S. Ivanovs ${ }^{2}, \bar{A}$. Rucins $\check{s}^{2}$
}

K ops a vi $1 \mathrm{ku} \mathrm{ms}$

Kaņepes ir daudzfunkcionāls materiāls, kas var tikt izmantots dažādās nozarēs. Šis pētījums ir vērsts uz iespējām izmantotkaņepju šķiedras kāizejvielu siltumizolācijas izstrādājumu ražošanai. Kaņepju šķiedru izolācijas galvenās priekšrocības ir saistītas ar veselības un vides drošību. Tirgū esošo kaņepju siltumizolācijas produktu siltumvadītspēja tiek salīdzināta ar citu siltumizolācijas materiālu fizikālajām īpašībām. Tirgus izpēte liek secināt, ka jauna tipa kaņepju šķiedru izolāciju materiālu, kuru izmaksas ir efektīvas, izstrāde ir perspektīvs virziens.

10.12.2014 